\title{
Research on the Influence of Reliability and Brand Image on Purchase Intention of Sports Brands Endorsed by Entertainers: A Case Study of Adidas Endorsed by Chun-Ning Chang
}

\author{
Yu-Ching Lo ${ }^{1}$, Kuo-Wei Lin ${ }^{2 *}$ \\ ${ }^{1}$ Lecturer, Physical Education Office, Hsin Sheng Junior College of Medical Care and Management, 325, Taiwan, Taoyuan City, Lon gtan District, \\ Taiwan \\ ${ }^{2}$ Assistant Professor, Physical Education Office, Yuan Ze University, No. 135, Yuandong Rd, Zhongli District, Taoyuan City, Taiwan
}

DOI: $10.36348 /$ jaspe.2020.v03i03.002 | Received: 29.02.2019| Accepted: 07.03.2020 | Published: 10.03 .2020

*Corresponding author: Kuo-Wei Lin

Abstract

The purpose of this study is to explore the influence of reliability and brand image on purchase intention of sports brands endorsed by entertainers. A questionnaire survey is conducted in this study, and the students from Hsin Sheng Junior College of Medical Care and Management are taken as research objects. A total of 300 questionnaires are sent out; after the deduction of 5 invalid questionnaires, a total of 295 valid questionnaires are collected. In this study, SPSS20.0 for Window Chinese package statistical software is used as the analysis tool. After the verification of descriptive statistics, reliability analysis, independent sample t test, Pearson product difference correlation analysis, and regression analysis, the results obtained are as follows: The reliability of entertainer endorsement has a significant impact on purchase intention, in which the influence of reliable image is greater than the influence of the attractiveness on purchase intention; Brand image has a significant influence on purchase intention, in which the effect of functionality in brand image is greater than the effect of symbolism in brand image on purchase intention; The reliability, brand image, and purchase intention of entertainer endorsement are significantly correlated. According to the results of this study, it is suggested that the selection of endorsers for sports brand companies must be consistent with the positive image of sports brand and have the popular impression, so as to attract consumers' recognition and expectation of products and provide references for relevant manufacturers.

Keywords: Entertainer endorsement, brand image, purchase intention.

Copyright @ 2020: This is an open-access article distributed under the terms of the Creative Commons Attribution license which permits unrestricted use, distribution, and reproduction in any medium for non-commercial use (NonCommercial, or CC-BY-NC) provided the original author and source are credited.

\section{INTRODUCTION}

\section{RESEARCH BACKGROUND AND MOTIVATION}

In recent years, with the increase of people's awareness of healthy life and the popularity of sports fashion, the demand for sports is not only for the wellbeing, but also one of the representatives of popular culture and fashion. Combining sports with fashion has become the mainstream and trend of the art of living today [27]. At the same time, consumer demand for sports goods has also increased. Therefore through well-known artists to serve as endorsers of sports brand, the sports brands try to increase the exposure of brand image, and strengthen sports peripheral products, so as to attract consumers' purchase intention.

The research of Lim [13] discovers that the correlation between endorsers and products could improve the reliability of endorsers and increase the positive impression of consumers on products. The research of Lin, Tsay, \& Chen [15], points out that brand image refers to consumers' perception of the internal and external attributes of products or their impression on the brand, which in turn results in purchase behavior or purchase intention. Yen [25] suggests that brand associations, which are consumers' subjective perceptions, are communication tools between enterprises and consumers. The research of Kao, Lin, \& Yen [10], indicates that the exposure rate of endorsers would increase the popularity of the endorser, and the popularity would affect consumers' cognition of the professionalism, attractiveness and reliability of the endorser. Many empirical studies have pointed out that the image and reliability of endorsers are included in the key factors influencing the image or purchase intention of sports brands [3, 8, 9, 12, 21]. Therefore, the influence of brand endorsers should not be underestimated. 
Under the trend of internationalization, most sports brands tend to invite international sports celebrities to endorse, while non-sports celebrities are less noticed [20]. Sports brands hope that consumers could increase their consumption power through the recognition of athletes' ability, performance and image; as a result, athletes more often become endorsers for sporting goods than models, movie stars or politicians [4]. In view of the past related research, most of them explore athletes as endorsers of a corporate brand or a leisure sports brand $[7,9,11,12,21]$. Therefore, when sports brands invite famous entertainer to act as brand spokesmen, it is worth discussing whether it could influence the brand image and thus generate consumers' purchase intention.

\section{Research purposes}

Based on the above research background and motivation, the following are the research objectives to be achieved:

- To understand the influence of endorsers' reliability on consumers' purchase intention.

- To understand the influence of brand image on consumers' purchase intention.

- To understand the correlation between endorsers' reliability, brand images, and consumers' purchase intention.

\section{Research Hypothesis}

According to the purpose of the study, this study assumes:

- The reliability of entertainer endorsement has a significant impact on purchase intention.

- Brand image has a significant influence on purchase intention.

- The reliability, brand image, and purchase intention of entertainer endorsement are significantly correlated.

\section{RESEARCH SCOPE AND LIMITATIONS The Limitations of Inference in Research}

The subjects of this study are the students from Hsin Sheng Junior College of Medical Care and Management, not including the students from other schools. Therefore, there are limitations of inference in this research, and the results and explanations of the research are limited to this school. As for the situation in other schools, further discussion and research are needed.

\section{Limitations of Research Methods}

In this study, a self-filled questionnaire is used to obtain the resources of the subject, and the questionnaire is issued and recovered by the researcher. It is impossible to completely control the standardized situation and the mentality of the subjects. Therefore, there is the possibility of false answers, so there might be errors in the research results.

\section{Glossary \\ Brand Endorser}

Brands could not only achieve good advertising results, but also increase brand awareness and thus enhance consumers' purchase intention by using wellknown entertainers with fresh, healthy, energetic and trustworthy images and charm as brand endorsers. According to the research of Chang [5], in order to strongly recommend their products, many businessmen often use endorsers' or referrers' popularity to assist companies in product sales or brands packaging to improve the effect. Bianchi and Pike [1] discover that celebrity endorsers are of great importance due to consumers' desire for celebrities.

\section{Brand Image}

Consumers' and the overall market's perception of the brand refers to the brand image, which is also the way to integrate all information into the product, such as product attributes and functionality [18]. Brand image exists in the memory of consumers. The association with the brand reflects the recognition and identification of the brand. The combination of consumers' perception of brands, that is, the concept of consumers' perception of brands, could help consumers identify and recognize the differences among product brands [23]

\section{Purchase Intention}

When consumers choose a product, they search for relevant information based on their own empirical and external environment. When the information reaches a certain level, consumers begin to evaluate and consider, after comparison and evaluation, and then generate purchase behavior [22]. The positive brand image and brand awareness of consumers would produce a higher purchase intention [19].

\section{RESEARCH METHOD \\ Research Framework}

This study first analyzes the sample structure of the recovered samples, and then analyzes the causal analysis of "endorser reliability", "brand image" and "purchase intention". This study comprehensively studies the motivation and research purposes, and refers to the theories of scholars, Biel [2], Miciak and Shanklin [16], and Zajonc and Markus [26].

\section{Research object}

The subjects of this study are the students from Hsin Sheng Junior College of Medical Care and Management. A formal questionnaire survey was conducted from May 1 to May 30, 2019, and the questionnaires were distributed by the researcher in class. There are 300 copies and all of them are recovered. 5 copies of invalid questionnaires are deducted, 295 copies of valid questionnaires are collected. The rate of valid questionnaire is $98 \%$. 


\section{Research tools}

In this study, relevant literature and theories are collected, and pre-test questionnaires are prepared, which are divided into four parts: basic personal information, endorsers' reliability scale, brand image scale and purchase intention scale.

\section{Basic personal information}

There are 5 questions in total to obtain the demographic information and supporting endorsers' information of the subjects.

\section{Endorsers' reliability scale}

This study is based on the research of Yeh [24], with attractiveness, reliability and professionalism as the facets of the endorsers' image in this study. It is revised according to the needs of this study. There are 12 questions in this part. Likert five-point scale is used to measure the degree of consumer consent on the reliability of endorsers.

\section{Brand Image Scale}

Based on the research of Lim [13], this study divides brand image into functional, symbolic and empirical. Therefore, this study explores the influence of three elements in brand image: functional, symbolic and empirical. There are 12 questions in this part. Likert five-point scale is used to measure the degree of consumer consent on brand image.

\section{Purchase intention scale}

This study refers to the scale in the study of Lin [14]. A total of 4 questions are used as a measurement tool of purchase intention. Likert fivepoint scale is used to measure the degree of consumer consent on purchase intention.

\section{Data analysis}

In this study, SPSS20.0 statistical software package is used to analyze the sample data. Descriptive statistical Analysis, Reliability Analysis, independent sample t-test and one-way ANOVA, Pearson's Correlation Analysis, Regression Analysis, etc. are used to analyze.

\section{ANALYSIS AND RESULTS \\ Descriptive statistics}

After the distribution of 300 questionnaires in this study, 300 questionnaires are collected. After reviewing the data content and deleting 5 invalid questionnaires, a total of 295 valid questionnaires are actually collected, and the effective questionnaire recovery rate is $98 \%$. In terms of gender, 14 of the subjects are males, accounting for $4.7 \%$; and 281 are females, accounting for $95.3 \%$.

\section{Exercise Habits}

There are 178 people without regular exercise habits, accounting for $60.3 \%$. There are 100 people work out one to two days a week, accounting for $33.9 \%$. There are 17 people work out more than three days per week, accounting for $5.8 \%$.

\section{Part-Time Job}

There are 154 people working part-time, accounting for $52.2 \%$. There are 141 people not working, accounting for $47.8 \%$.

Total amount of sports brand products purchased each year

The total amount of sports brand products purchased each year is less than NT \$1,000, with a total of 120 people, accounting for $40.7 \%$; followed by NT $\$ 1,001$ - NT \$5,000, with 113 people, accounting for $38.3 \%$.

\section{The channel of purchasing sporting goods}

When purchasing sporting goods, the majority, 106 people, shop at sporting goods stores, accounting for $35.9 \%$; followed by 70 people shopping on line, accounting for $23.7 \%$.

Table-1: Sample demographic variable description analysis table

\begin{tabular}{|l|l|l|l|}
\hline Variable & Item & $\begin{array}{l}\text { Number of } \\
\text { people }\end{array}$ & Percentage \% \\
\hline \multirow{3}{*}{ Gender } & Male & 14 & 4.7 \\
\cline { 2 - 4 } & Female & 281 & 95.3 \\
\hline \multirow{4}{*}{ Exercise habits } & without regular exercise habits & 178 & 60.3 \\
\cline { 2 - 4 } & work out 1-2 days a week & 100 & 33.9 \\
\cline { 2 - 4 } & work out more than 3 days a week & 17 & 5.8 \\
\hline \multirow{3}{*}{ Part-time job } & working part-time & 154 & 52.2 \\
\cline { 2 - 4 } & not working & 141 & 47.8 \\
\hline \multirow{2}{*}{$\begin{array}{l}\text { Total amount of sports brand } \\
\text { products purchased each year }\end{array}$} & \NT \$1,000 & 120 & 40.7 \\
\cline { 2 - 4 } & NT \$1,001- NT \$5,000 & 113 & 38.3 \\
\cline { 2 - 4 } & NT \$5,001- NT \$10,000 & 56 & 19.0 \\
\cline { 2 - 4 } & NT \$10,001- NT \$15,000 & 6 & 2.0 \\
\cline { 2 - 4 } & $\geqq$ NT \$15000 & 0 & 0 \\
\hline \multirow{3}{*}{$\begin{array}{l}\text { The channel of purchasing sporting } \\
\text { goods }\end{array}$} & Sporting goods store & 106 & 35.9 \\
\cline { 2 - 4 } & Shopping center & 67 & 22.7 \\
\cline { 2 - 4 } & Supermarket & 33 & 11.2 \\
\cline { 2 - 4 } & Outlet & 19 & 6.4 \\
\cline { 2 - 4 } & Online & 70 & 23.7 \\
\hline
\end{tabular}




\section{Reliability Analysis}

This research mainly uses the Cronbach 's $\alpha$ coefficient to measure the internal consistency between the reliability of endorsers, brand image, and their details on purchase intention. Scholar Nunnally [17] believes that $>0.7$ is a high reliability; while $0.5<\alpha$ $<0.7$ is a low, but acceptable marginal value of the scale; if the $\alpha$ coefficient value is less than 0.5 , it cannot be used.

Table-2 Reliability analysis scale

\begin{tabular}{|l|l|l|}
\hline Facet & Cronbach' $\alpha$ value & Cronbach 'values for the whole questionnaire \\
\hline Reliability of endorsers & 1.039 & \\
\cline { 2 - 3 } Brand image & 0.934 & 1.017 \\
\cline { 2 - 3 } Purchase intention & 1.079 & \\
\hline
\end{tabular}

\section{Analysis of Endorsers' Reliability}

In terms of endorsers' reliability, this study includes three facets: attractiveness, credibility, and professionalism. As can be seen from Table-3, consumers tend to agree with most of the sources of endorsement reliability.

Table-3: The summary table of endorsers' reliability in the description analysis

\begin{tabular}{|c|c|c|c|c|}
\hline Facet & Variable & Mean & $\begin{array}{l}\text { Standard } \\
\text { deviation }\end{array}$ & $\begin{array}{l}\text { Cronbach's } \\
\alpha\end{array}$ \\
\hline \multirow[t]{4}{*}{ Attractiveness } & 1. Her youthful attracts me. & 4.16 & 0.930 & \\
\hline & 2. She is the endorser of the brand because she is attractive. & 4.12 & 0.927 & \\
\hline & 3. She is popular because of her beauty and temperament. & 3.90 & 0.991 & \\
\hline & 4. Her endorsement of Adidas is very attractive. & 4.04 & 1.980 & \\
\hline \multirow[t]{4}{*}{ Credibility } & 5. She has a trustworthy image. & 4.13 & 0.945 & \\
\hline & 6. She has affinity so she becomes the endorser. & 4.17 & 0.919 & 1.039 \\
\hline & 7. She has positive and healthy qualities. & 4.24 & 0.901 & \\
\hline & 8. She has a fresh and good image. & 4.24 & 0.911 & \\
\hline \multirow[t]{4}{*}{ Professionalism } & $\begin{array}{l}\text { 9. From my perspective, her endorsement makes the brand } \\
\text { professional. }\end{array}$ & 3.93 & 1.038 & \\
\hline & 10. Her passion for sports draws me deeply. & 4.01 & 1.013 & \\
\hline & 11. She loves sports and could endorse sports brands. & 4.06 & 0.972 & \\
\hline & 12. She has a wealth of professional knowledge about sports. & 4.03 & 0.944 & \\
\hline
\end{tabular}

\section{Brand Image}

In terms of brand image, it can be seen from table 4 that most consumers tend to agree on the functionality, symbolism and empirical provided by brand image.

Table-4: Descriptive statistical scale for brand image facets

\begin{tabular}{|l|l|l|l|l|}
\hline Facet & Variable & Mean & Standard deviation & Cronbach's $\boldsymbol{\alpha}$ \\
\hline \multirow{5}{*}{ Functionality } & 1. The quality of Adidas products is excellent. & 4.36 & 0.761 & \\
\cline { 2 - 5 } & 2. Adidas products look beautiful. & 4.31 & 0.776 & \\
\cline { 2 - 5 } & 3. Adidas products' function is very well. & 4.31 & 0.789 & \\
\cline { 2 - 5 } & 4.Adidas products are durable. & 4.34 & 0.765 & 0.934 \\
\hline \multirow{5}{*}{ Empolism } & 5. Adidas is highly professional. & 4.30 & 0.812 & \\
\cline { 2 - 5 } & 6. Adidas has a good reputation. & 4.42 & 0.764 & \\
\cline { 2 - 5 } & $\begin{array}{l}\text { 7. Adidas could be regarded as a symbol of } \\
\text { social status. }\end{array}$ & & 1.05 & \\
\cline { 2 - 5 } & 8. Adidas is the leading brand of sports brands. & 4.15 & 0.928 & \\
& 9. Adidas could give me pleasure. & 4.14 & 0.905 & \\
\cline { 2 - 5 } & 10. Adidas is fashionable. & 4.25 & 1.825 & \\
\cline { 2 - 5 } & 11. Adidas could reflect my personal style. & 4.06 & 0.938 & \\
\cline { 2 - 4 } & 12. Adidas is reasonably priced. & 4.04 & 0.932 & \\
\hline
\end{tabular}

\section{Purchase Intention}

As can be seen in Table-5, consumers are positive about whether they would consider buying. 
Table-5: Descriptive statistical scale for purchase intention facets

\begin{tabular}{|l|l|l|l|}
\hline \multicolumn{1}{|c|}{ Variable } & Mean & $\begin{array}{l}\text { Standard } \\
\text { deviation }\end{array}$ & $\begin{array}{l}\text { Cronbach's } \\
\boldsymbol{\alpha}\end{array}$ \\
\hline 1. I am willing to buy the brand endorsed by Chun-Ning Chang. & 3.87 & 0.997 & 1.079 \\
\hline $\begin{array}{l}\text { 2. I would like to recommend the brand endorsed by Chun-Ning } \\
\text { Chang to friends. }\end{array}$ & 3.79 & 1.004 & \\
\hline $\begin{array}{l}\text { 3. If there are similar products, I will only buy the products endorsed } \\
\text { by Chun-Ning Chang. }\end{array}$ & 3.62 & 1.189 & \\
\hline 4. I would buy the product endorsed by Chun-Ning Chang next time. & 3.71 & 1.129 & \\
\hline
\end{tabular}

T-test and analysis of variance for independent samples

This section mainly discusses the independent sample t test of gender on endorsers' reliability, brand image and purchase intention. The results do not show significant differences.

Table-6: The independent sample t test of gender on endorsers' reliability, brand image and purchase intention

\begin{tabular}{|l|l|l|l|l|l|l|}
\hline Facet & Gender & Number of people & Mean & Standard deviation & t & p-value \\
\hline \multirow{2}{*}{ Endorsers' reliability } & Male & 14 & 3.45 & 1.288 & -2.850 & 0.345 \\
\cline { 2 - 7 } & Female & 281 & 4.11 & 0.855 & -1.203 & 0.053 \\
\hline \multirow{2}{*}{ Brand image } & Male & 14 & 4.01 & 0.897 & -1.502 & 0.232 \\
\cline { 2 - 7 } & Female & 281 & 4.23 & 0.845 & -0.866 & 0.051 \\
\hline \multirow{2}{*}{ Purchase intention } & Male & 14 & 3.07 & 1.297 & -2.233 & 0.346 \\
\cline { 2 - 7 } & Female & 281 & 3.78 & 1.042 & -1.665 & 0.063 \\
\hline
\end{tabular}

Relevant analysis of endorsers' reliability, brand image, and purchase intention

\section{Endorsers' reliability and purchase satisfaction}

After Pearson correlation analysis in this study,

it can be seen from table 7 that the p-values of attractiveness, reliability and professionalism are all less than.05, which have a significant impact on consumers' purchase intention. The endorser's attractiveness is highly correlated with reliability.

Table-7: Relevance table of attractiveness, credibility and professionalism to purchase intention

\begin{tabular}{|c|c|c|c|c|c|}
\hline Facet & & Attractiveness & Reliability & Professionalism & Purchase intention \\
\hline \multirow{4}{*}{$\begin{array}{l}\text { Pearson } \\
\text { correlation }\end{array}$} & Attractiveness & 1.000 & 0.858 & 0.782 & 0.651 \\
\hline & Credibility & 0.858 & 1.000 & 0.817 & 0.656 \\
\hline & Professionalism & 0.782 & 0.817 & 1.000 & 0.643 \\
\hline & Purchase intention & 0.295 & 0.656 & 0.295 & 1.000 \\
\hline \multirow{4}{*}{$\begin{array}{l}\text { Significance } \\
\text { (two-tailed) }\end{array}$} & Attractiveness & & $0.000 * *$ & $0.000 * *$ & $0.000 * *$ \\
\hline & Credibility & $0.000 * *$ & & $0.000 * *$ & $0.000 * *$ \\
\hline & Professionalism & $0.000 * *$ & $0.000 * *$ & & $0.000 * *$ \\
\hline & Purchase intention & $0.000 * *$ & $0.000 * *$ & $0.000 * *$ & \\
\hline
\end{tabular}

\section{Brand image and purchase intention}

Functionality, symbolism, and empirical of brand image are significantly related to purchase intention. It can be seen from Table- 8 that the p-value of the brand image's functional, symbolic, and empirical value for purchase intention is less than 0.05 and has a correlation with consumer purchase intention.

Table-8: Relevance table of functionality, symbolism, and empirical to purchase intention

\begin{tabular}{|l|l|l|l|l|l|}
\hline Facet & & Functionality & symbolism & empirical & purchase intention \\
\hline \multirow{5}{*}{ Pearson correlation } & Functionality & 1.000 & 0.637 & 0.665 & 0.534 \\
\cline { 2 - 6 } & symbolism & 0.637 & 1.000 & 0.752 & 0.635 \\
\cline { 2 - 6 } & empirical & 0.665 & 0.752 & 1.000 & 0.649 \\
\cline { 2 - 6 } & purchase intention & 0.534 & 0.635 & 0.295 & 1.000 \\
\hline Significance (two-tailed) & Functionality & & $0.000^{* *}$ & $0.000^{* *}$ & $0.000^{* *}$ \\
\cline { 2 - 6 } & symbolism & $0.000^{* *}$ & & $0.000^{* *}$ & $0.000^{* *}$ \\
\cline { 2 - 6 } & empirical & $0.000^{* *}$ & $0.000^{* *}$ & & $0.000^{* *}$ \\
\cline { 2 - 6 } & purchase intention & $0.000^{* *}$ & $0.000^{* *}$ & $0.000^{* *}$ & \\
\hline
\end{tabular}

$$
\mathrm{N}=295, * \mathrm{p}<.05, * * \mathrm{p}<.01, * * * \mathrm{p}<.001
$$


Relevant analysis of endorsers' reliability and brand image on purchase intention

Endorsers' reliability and brand image have significant effect on purchase intention. Reliability and brand image are highly correlated to purchase intention, and it could be seen from Table- 9 that the p-values are all less than 0.05 .

Table-9: Correlation analysis table of endorsers' reliability, brand image and purchase intention

\begin{tabular}{|l|l|l|l|l|}
\hline & Level & Endorsers' reliability & Brand image & Purchase intention \\
\hline \multirow{2}{*}{ Endorsers' reliability } & Pearson correlation & 1 & 0.815 & 0.529 \\
\cline { 2 - 5 } & Significance (two-tailed) & & $0.000^{* *}$ & $0.000^{* *}$ \\
\hline \multirow{2}{*}{ Brand image } & Pearson correlation & 0.815 & 1 & 0.534 \\
\cline { 2 - 5 } & Significance (two-tailed) & $0.000^{* *}$ & & $0.000^{* *}$ \\
\hline \multirow{2}{*}{ Purchase intention } & Pearson correlation & 0.529 & 0.534 & 1 \\
\cline { 2 - 5 } & Significance (two-tailed) & $0.000^{* *}$ & $0.000^{* *}$ & \\
\hline
\end{tabular}

$\mathrm{N}=295, * \mathrm{p}<.05, * * \mathrm{p}<.01, * * * \mathrm{p}<.001$

\section{Regression Analysis}

This section mainly explores the relationship between endorsers' reliability, brand image, and purchase intention. The multiple regression analysis is used to test the relationship between this independent variable and purchase intention depending on the variable.

The analysis results in table 10 show that the multiple regression analysis of purchase intention is significant and has an impact on purchase intention.

Table-10: Regression analysis

\begin{tabular}{|l|l|l|l|l|c|}
\hline & Unstandardized coefficient & standardized coefficient & \multirow{2}{*}{ s } & \multirow{2}{*}{ significance } \\
\cline { 2 - 5 } & Estimated $\boldsymbol{\beta}$ & Standard error & $\boldsymbol{\beta}$-distribution & & \\
\hline (Constant) & -426 & 0.203 & & -2.096 & 0.037 \\
\hline Attractiveness & 0.028 & 0.076 & 0.021 & 0.362 & 0.717 \\
\hline Credibility & 0.023 & 0.085 & 0.022 & 0.276 & 0.783 \\
\hline Professionalism & -0.059 & 0.077 & -0.045 & -0.767 & 0.555 \\
\hline Functionality & 0.324 & 0.093 & 0.198 & 2.315 & 0.021 \\
\hline Symbolism & 0.470 & 0.050 & 0.305 & 6.587 & 0.000 \\
\hline Empirical & 0.175 & 0.070 & 0.166 & 2.586 & 0.013 \\
\hline $\mathrm{N}=295, * \mathrm{p}<.05, * * \mathrm{p}<.01, * * * \mathrm{p}<.001$ & & & \\
\hline
\end{tabular}

\section{CONCLUSION AND RECOMMENDATION CONCLUSION}

This research mainly explores the influence of the reliability of the entertainers' endorsement of sports brand and the brand image on purchase intention. The verification results are analyzed as follows:

\section{Correlation analysis of endorsers' credibility and purchase intention}

According to the analysis results, it is found that endorses' reliability has a significant correlation with consumers' purchase intention. The research of scholar Lim [13] points out that the endorsers' reliability has a positive impact on consumers' purchase intention, which is consistent with the findings of this research. Therefore, consumers would have a positive impression on the attractiveness, credibility and product image of the endorsement from the well-known entertainer, thus increasing consumers' purchase intention.

Correlation analysis between brand image and purchase intention

According to the analysis results, there is a significant correlation between brand image and purchase intention. The research of Cheng, Chen, Chen [6] shows that the better the brand image, the higher the degree of purchase intention, which is consistent with the findings of this study. Therefore, a good brand image gives consumers a sense of trust, thus enhancing consumers' purchase intention.

Correlation analysis of endorsers' reliability, brand image and purchase intention

According to the analysis results, it is found that the endorsers' reliability and the degree of brand image are highly correlated with consumers' purchase intention. According to the research of scholar Yeh [24], when the endorser has high reliability, the brand image and purchase intention would also be improved, which is consistent with the research results of this study. Therefore, brand reliability and brand image endorsed by well-known entertainer have a significant impact on consumers' purchase intention.

\section{RESEARCH LIMITATIONS RECOMMENDATIONS}

AND

Due to human factors and time, this study focused only on the students from Hsin Sheng Junior College of Medical Care and Management, and the 
gender ratio of male and female students is very different. Therefore, it fails to represent the consumption behavior pattern of most students. It is suggested that when the questionnaire is issued, the verification of different schools and regions should be added to achieve an objective and fair verification analysis.

\section{REFERENCES}

1. Bianchi, C., \& Pike, S. (2011). Antecedents of destination brand loyalty for a long-haul market: Australia's destination loyalty among Chilean travelers. Journal of Travel and Tourism Marketing, 28(7):736-750.

2. Biel, A. (1992). How brand image drives brand equity. Journal of Advertising Research, 32:6-12.

3. Bower, A. B., \& Landreth, S. S. (2001). Is beauty best? Highly versus normally attractive models in advertising. Journal of Advertising, 30, 1-12.

4. Carlson, D. B., \& Donavan, D. T. (2008). Concerning the effect of athlete endorsements on brand and team related intentions. Sport Marketing Quarterly, 17(3):154-162.

5. Chang, Y. J. (2015). The research of the ageless spokeswoman's credibility and female customers' purchase intention- facial skin care products as the example (Unpublished master's thesis). Tamkang University, New Taipei City, Taiwan (ROC).

6. Cheng, Q. Y., Chen F. L., \& Chen, Y. H. (2017). Brand image and brand trust on customer purchase intention - for example, department of management science, ROCMA. WHAMPOA - An Interdisciplinary Journal, 72, 51-60.

7. Garry, J. M. (2006). The effectiveness of sports brand endorser's credibility on consumers buying decision - Case: Nike and Adidas' basketball endorsers for research purpose (Unpublished master's thesis). National Sun Yat-sen University, Kaohsiung City, Taiwan (ROC).

8. Hsu, L. L. (2005). The Impacts of Endorsers and Their Credibility on Consumers' Intentions to Participate in Sports and Purchase Sports Shoes (Unpublished master's thesis). National Taiwan Normal University, Taipei City, Taiwan (ROC).

9. Hsueh, C. C., \& Lee, C. J. (2008). The effects of athlete's endorser credibility on brand image and purchase intention - a case study of Chien-Ming Wang. Proceedings of the Symposium on Sports Business Management, 148-162.

10. Kao, C. L., Lin, Y. N., \& Yen, J. C. (2019). A study of the relationship among endorsers' credibility, advertising effectiveness and purchase intention. Delin Journal, 32, 71-84.

11. Kuo, Y. L. (2007). The marketing effect of professional sport players as product spokesperson in Taiwan (Unpublished master's thesis). Tainan University of Technology, Tainan City, Taiwan (ROC).

12. Lee, Y. K. (2009). A study of the relationships among endorser's credibility, perception of the product and purchase intentions - take ChienMing Wang as an example (Unpublished master's thesis). National Kaohsiung Normal University, Kaohsiung City Tainan City, Taiwan (ROC).

13. Lim, Z. X. (2016). The study of the credibility of badminton brand spokesperson on consumer purchase intention: a case of YONEX brand (Unpublished master's thesis). Chaoyang University of Technology, Taichung City, Taiwan (ROC).

14. Lin, C. H. (2010). The impact of brand image on consumer's purchase intention for automobile industry in Taiwan - an example of automobile made in Taiwan (Unpublished master's thesis). Chaoyang University of Technology, Taichung City, Taiwan (ROC).

15. Lin, Y. S., Tsay, C. Y., \& Chen, M. (2013). Study on the impact of brand image and service quality on brand loyalty for customers-an example case of $85^{\circ} \mathrm{C}$ Coffee chain stores in Pingtung area. Yu Da Acadamic Journal, 35:130.

16. Miciak, A. R., \& Shanklin, W. L. (1994). Choosing entertainer endorsers. Marketing Management, 3:50-60.

17. Nunnally, J. C. (1978). Psychometric Theory. New York: McGraw-Hill.

18. Pang, J. C. (2017). The impact of sharing economy and brand image on the behavioral intention to use Uber (Unpublished master's thesis). Tunghai University. Taichung City, Taiwan (ROC).

19. Romaniuk, J., \& Sharp, B. (2003). Measuring brand perceptions: Testing quantity and quality. Journal of Targeting, Measurement and Analysis for Marketing, 11(3), 218-229.

20. Roy, S., \& Pansari, A. (2014). Owner or endorser? Investigating the effectiveness of entertainer owners of sports teams as endorsers. International Journal of Sports Marketing \& Sponsorship, 15(2), 12-29.

21. Tsai, S. M. (2002). A study on impact of sports brand spokespersons' source credibility on consumer's intention to purchase (Unpublished master's thesis). National Taiwan University of Science and Technology, Taipei City, Taiwan (ROC).

22. Tsai, Y. C., \& Cheng, Y. S. (2016). The influence of department stores anniversary promotion activity on customer purchase intention. Journal of Chinese Economic Research, 14(2), 75-89.

23. Wang, Y., \& Liu, W. T. (2008). The influence of promotion and brand image toward consumers' perceived value and their purchase intentiontake women's clothing brands as examples, Taiwan Textile industry value added and innovation conference in 2008, Taipei City, 
Taiwan (ROC).

24. Yeh, H. Y. (2011). A case study on sports brand endorser's credibility, brand image, advertising effectiveness, and purchase intention in the case of Adidas (Unpublished master's thesis). National Taiwan Normal University, Taipei City, Taiwan (ROC).

25. Yen, C. P. (2017). A study related to brand image and purchase intention of ultimate players' athletic shoes - an example of 2016 citizen's sports games (Unpublished master's thesis). National Kaohsiung Normal University, Kaohsiung City, Taiwan (ROC).

26. Zajonc, R. B. \& Markus, H. (1982). Affective and cognitive factors in preferences. Journal of Consumer Research, 9:123-131.

27. Zhou, G. X. (2015). On the influence of sports fashion on high street fashion. Sports Vision, 5(33):238-239. 